\title{
Role of NMDA and Non-NMDA Receptors in Excitatory Postsynaptic Potentials in Rat Suprachiasmatic Nucleus Neurons
}

\author{
SHINGO SHOJI*, HIROSHI HASUO ${ }^{\dagger}$, TAKASHI AKASU $^{\dagger}$ \\ AND MASARU ISHIMATSU*† \\ *Department of Endocrinology and Metabolism and Department of Physiology, \\ Kurume University School of Medicine, Kurume, 830 Japan
}

Received for publication March 18, 1992

\begin{abstract}
Key words: Suprachiasmatic nucleus - EPSP - NMDA and non-NMDA receptors - intracellular recording - optic nerve
\end{abstract}

The suprachiasmatic nucleus (SCN) is the site of a putative pacemaking oscillator for the regulation of circadian rhythms in mammals (Nishino et al. 1976; Rusak and Zucker, 1979; Turek, 1985; Meijer and Rietveld, 1989). The SCN receives visual information from the retinohypothalamic tract (RHT) (Moore, 1973; Millhouse, 1977; Pickard, 1982) and indirectly via the retino-geniculo-suprachiasmatic pathway (RGSP) (Swanson et al. 1974; Pickard, 1985). Entrainment of the mammalian circadian system by light cycles and the phase shifting of responses of the system to short light pulses are mediated by these inputs to the SCN (Moore, 1973; Inouye and Kawamura, 1982). Extracellular recordings of singleor multiple-unit activity have indicated that glutamate and/or aspartate mediate transmission in the retinal projection to the SCN (van den Pol and Tsujimoto, 1985; Liou et al. 1986; Shibata et al. 1986; Cahill and Menaker, 1987). In the present study, intracellular recordings were obtained from neurons of the SCN using a rat brain slice preparation, and the roles of amino acid receptors in excitatory postsynaptic potentials were ex- amined.

Brain slices containing the SCN were obtained from male Wistar-Kyoto rats weighing $200-300 \mathrm{~g}$. The rats were maintained in a temperature-controlled room $\left(22-25{ }^{\circ} \mathrm{C}\right)$ and exposed to a $14: 10 \mathrm{~h}$ lightdark cycle. The rats were sacrificed by decapitation, and their brains were rapidly removed and immersed for 8-10 sec in a cooled artificial cerebrospinal fluid (Krebs solution) $\left(4-6{ }^{\circ} \mathrm{C}\right)$ prebubbled with $95 \% \mathrm{O}_{2}-5 \% \mathrm{CO}_{2}$. Coronal hypothalamic slices $(500 \mu \mathrm{m}$ in thickness) containing the entire SCN and the optic chiasm were cut with a Vibroslice (Campden Instruments Ltd.). Slices were submerged in a recording chamber and superfused at $32-34{ }^{\circ} \mathrm{C}$ with Krebs solution ( $\left.\mathrm{pH} 7.4\right)$ of the following composition $(\mathrm{mM}): \mathrm{NaCl}$, $117 ; \mathrm{KCl}, 4.7 ; \mathrm{CaCl}_{2}, 2.5 ; \mathrm{MgCl}_{2}, 1.2$; $\mathrm{NaHCO}_{3}, 25 ; \mathrm{NaH}_{2} \mathrm{PO}_{4}, 1.2$ and glucose, 11. Intracellular recordings of the membrane potential were made with glass microelectrodes filled with $4 \mathrm{M}$ potassium citrate $(100-140 \mathrm{M} \Omega$ ) and were amplified with an Axoclamp 2A (Axon Instruments). A concentric bipolar electrode was used for stimulation (monophasic, $0.05-0.1 \mathrm{msec}$ duration) of the optic chi-

Reprint requests to: Dr. Takashi Akasu, Department of Physiology, Kurume University School of Medicine, 67 Asahi-machi, Kurume, 830 Japan 

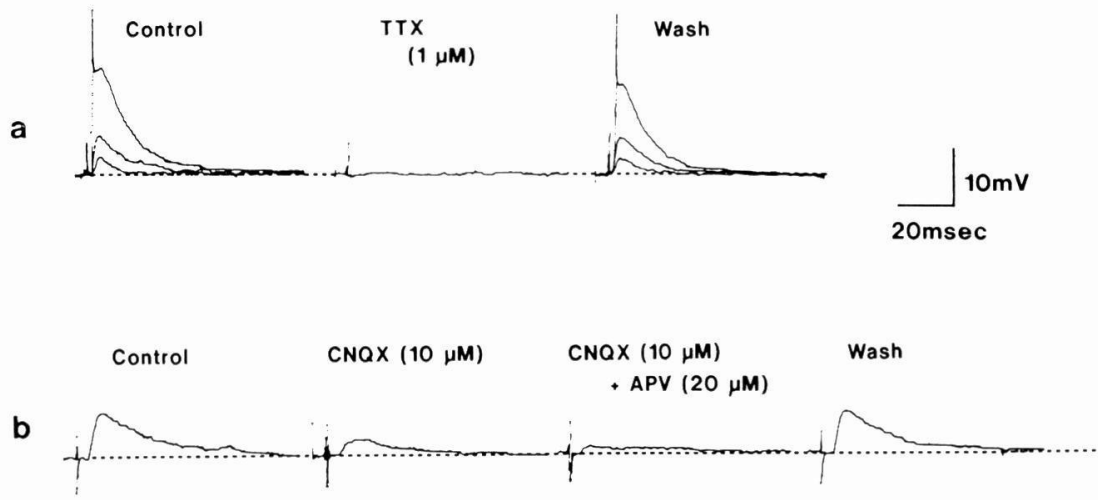

Fig. 1. Excitatory postsynaptic potentials (EPSPs) in a neuron of the suprachiasmatic nucleus ( $\mathrm{SCN}$ ) evoked by stimulation of the optic chiasm. The membrane potential was held at $-60 \mathrm{mV}$ by injection of anodal DC current. a. Tetrodotoxin $(1 \mu \mathrm{M})$ was applied in the superfusing solution for $5 \mathrm{~min}$. b. CNQX $(10 \mu \mathrm{M})$ was applied for $5 \mathrm{~min}$ and then APV $(20 \mu \mathrm{M})$ was added to the CNQX solution for $5 \mathrm{~min}$.

asm. Data are expressed as mean $\pm \mathrm{SE}$.

A majority of SCN neurons $(85 \%)$ had spontaneous action potentials. Focal stimulation of the optic chiasm produced graded depolarizing responses (excitatory postsynaptic potentials; EPSPs) which reached action potential threshold at high stimulus intensities (Fig. 1). The mean amplitude of the EPSPs evoked by lowintensity stimuli $(0.1 \mathrm{~Hz}, 5-15 \mathrm{~V})$ was $6 \pm$ $5 \mathrm{mV}(\mathrm{n}=4)$ at a membrane potential of $-60 \mathrm{mV}$. The EPSP was blocked by a solution containing TTX $(1 \mu \mathrm{M})$ (Fig. 1a). The EPSP increased in amplitude with membrane hyperpolarization, and decreased with depolarizing the membrane. The mean extrapolated reversal potential for the EPSP was $-15 \pm 5 \mathrm{mV}(\mathrm{n}=3)$.

6-Cyano-7-nitroquinoxaline-2, 3 -dione (CNQX, $10 \mu \mathrm{M})$, a non-NMDA receptor antagonist, partially reduced the EPSP. The residual component of the EPSP was blocked by D-2-amino-5-phosphonopentanoate (APV, $20 \mu \mathrm{M}$ ), an antagonist for $\mathrm{N}$-methyl-D-aspartate (NMDA) receptors (Fig. 1b). Bath-application of NMDA (10 $\mu \mathrm{M})$, kainate $(5-10 \mu \mathrm{M})$ or quisqualate

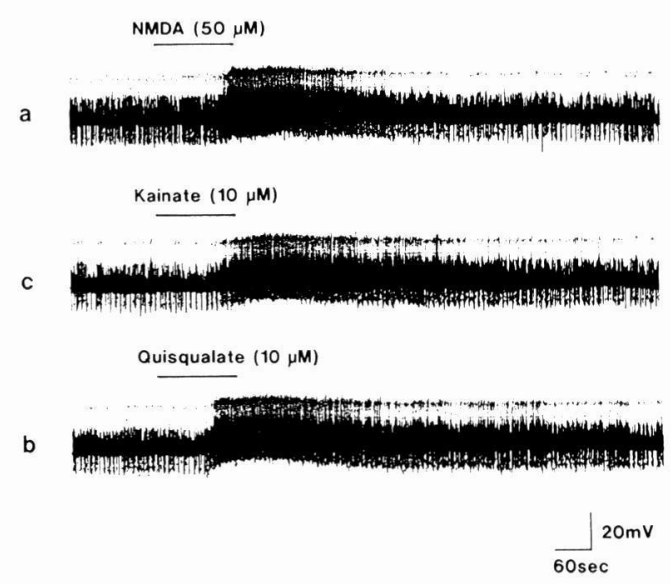

Fig. 2. Effects of NMDA $(50 \mu \mathrm{M})$, kainate $(10 \mu \mathrm{M})$ and quisqualate $(10 \mu \mathrm{M})$ on the membrane potentials of a SCN neuron. The horizontal bars indicate the periods for the superfusion of these drugs.

(1-5 $\mu \mathrm{M})$ depolarized the neuronal membrane of the SCN, thereby markedly increasing the frequency of the spontaneous action potentials (Fig. 2).

Some of the SCN neurons $(35 \%)$ had spontaneous EPSPs with amplitudes of 
1-2 $\mathrm{mV}$. The spontaneous EPSPs were blocked by a low calcium solution but not by the application of TTX $(1 \mu \mathrm{M})$, in dicating that they are miniature (m) EPSPs. Application of both APV $(10 \mu \mathrm{M})$ and CNQX $(20 \mu \mathrm{M})$ strongly reduced the mEPSPs.

In the present study, EPSPs in SCN neurons of rat brain slice preparations were evoked by stimulation of the optic chiasm. A previous study reported that stimulation of the optic nerve in a hypothalamic slice preparation induced the release of ${ }^{3} \mathrm{H}$-glutamate and ${ }^{3} \mathrm{H}$-aspartate in the SCN which was calciumdependent (Liou et al. 1986). A recent study, using extracellular recording techniques, has indicated that a NMDA receptor subtype mediates RHT transmission (Shibata et al. 1986), whereas other results supported a role for non-NMDA receptors (Cahill and Menaker, 1987). The present study demonstrated that either CNQX or APV produced only a partial reduction of the amplitude of the EPSP. The combined application of these drugs abolished the EPSP. Depolarizing responses in SCN neurons were produced by applications of agonists for NMDA and non-NMDA receptors, such as quisqualate, kainate and NMDA. Recently, Kim and Dudek (1991) reported that there were no miniature synaptic potentials. However, the present study has clearly shown the existence of mEPSPs in neurons of the rat SCN. The mEPSPs were blocked by antagonists for NMDA and non-NMDA receptors. These results indicate that both NMDA and non-NMDA receptors are present in postsynaptic $\mathrm{SCN}$ neurons and that they mediate excitatory transmission from the visual systems.

Acknowledgments: This work was supported by a Grant-in-Aid for Scientific Research from the Ministry of Education, Science and Culture of Japan.

\section{References}

Cahill, G. M. and Menaker, M. (1987). Kynurenic acid blocks suprachiasmatic nucleus responses to optic nerve stimulation. Brain Res. 410, 125-129.

Inouye, S. T. and Kawamura,H. (1982). Characteristics of a circadian pacemaker in the suprachiasmatic nucleus. J. Comp. Physiol. 146, 153-160.

KIM, Y.I. and DUDEK,F.E. (1991). Intracellular electrophysiological study of suprachiasmatic nucleus neurons in rodents: Excitatory synaptic mechanisms. J. Physiol. (Lond.) 444, 269-287.

Liou, S. Y., Shibata, S., Iwasaki, K. and Ueki, S. (1986). Optic nerve stimulation-induced increase of release of ${ }^{3} \mathrm{H}$-glutamate and ${ }^{3} \mathrm{H}$ aspartate but not ${ }^{3} \mathrm{H}$-GABA from the suprachiasmatic nucleus in slices of rat hypothalamus. Brain Res. Bull. 16, 527-531.

Meijer, J.H. and Rietveld, W. J. (1989). Neurophysiology of the suprachiasmatic circadian pacemaker in rodents. Physiol. Rev. 69, 671707.

Millhouse, O.E. (1977). Optic chiasm collaterals afferent to the suprachiasmatic nucleus. Brain Res. 137, 351-355.

MOoRe, R.Y. (1973). Retinohypothalamic projection in mammals: a comparative study. Brain Res. 49, 403-409.

Nishino, H., KoIzumi, K. and Brooks, C. McC. (1976). The role of suprachiasmatic nuclei of the hypothalamus in the production of circadian rhythm. Brain Res. 112, 45-59.

PicKard, G.E. (1982). The afferent connections of the suprachiasmatic nucleus of the golden hamster with emphasis on the retinohypothalamic projection. J. Comp. Neurol. 211, 65-83.

PICKARD, G.E. (1985). Bifurcating axons of retinal ganglion cells terminate in the hypothalamic suprachiasmatic nucleus and the intergeniculate leaflet of the thalamus. Neurosci. Lett. 55, 211-217.

RUSAK, B. and ZUCKER, I. (1979). Neural regulation of circadian rhythms. Physiol. Rev. 59, 449-526.

Shibata, S., Liou, S.Y. and Ueki, S. (1986). Influence of excitatory amino acid receptor antagonists and of baclofen on synaptic transmission in the optic nerve to the suprachiasmatic nucleus in slices of rat hypothalamus. 
Neuropharmacology 25, 403-409.

Swanson, L. W., Cowan, W.M. and Jones, E.G. (1974). An autoradiographic study of the efferent connections of the ventral lateral geniculate nucleus in the albino rat and the cat. J. Comp. Neurol. 156, 143-164.

Turek, F. W. (1985). Circadian neural rhythms in mammals. Ann. Rev. Physiol. 47, 49-64. van den Pol, A.N. and Tsujimoto, K.L. (1985). Neurotransmitters of the hypothalamic suprachiasmatic nucleus: immunocytochemical analysis of 25 neuronal antigens. Neuroscience 15, 1049-1086. 